\title{
Evaluation of the exercise intervention with the "Back School" Education Program in a Brazilian company of cigars: a case study
}

\author{
Sânzia Bezerra Ribeiro ${ }^{\mathrm{a}^{*}}$, Djeynefer Silveira Wagmacker ${ }^{\mathrm{b}}$, Lilian Becerra de Oliveira ${ }^{\mathrm{a}}$, \\ ${ }^{a}$ Professora mestre da Faculdade Adventista da Bahia. ${ }^{b}$ Fisioterapeuta graduada e posgraduada pela \\ Faculdade Adventista da Bahia, Br 101, Km 197, Caixa Postal 18, Capoeirçu-Cachoeira, BA-Brasil \\ sanziar@gmail.com
}

\begin{abstract}
The purpose of this study was to assess the benefits of an exercise program associated to the educational phase of the "Back School Program" in the quality of life of workers from a cigar factory. This is a case study conducted over four months with three activities a week, two times a day, with the third day devoted to educational activities, focusing on healthy lifestyle, correct posture, postural orientations, daily living and work activities, work motivation, and other issues.
\end{abstract}

Keywords: RSI, Life Quality, Work Physical Therapy, Labor Gymnastic and Back school.

\section{Introduction}

One of the problems that have affected most companies today is occupational diseases. In Brazil, in the year of 2009, 723,452 work accidents and diseases were registered in the Instituto Nacional de Seguro Social [INSS] (Social Insurance National Institute), where the statistics show that about 43 workers a day do not return to work due to invalidity or death [13].

The life quality at work today can be defined as a way of thinking involving people, work and organizations, where two important aspects are featured: The preoccupation with the well being of the worker, organizational efficiency, and the participation of the workers in work decisions and problems [20].

Through resolution number 259, of December $18^{\text {th }}, 2003$, it was determined that the physical therapist has the power to give assistance in the worker's health prevention, accomplished primarily through preventive measures, which will legally contribute to actions that will promote, prevent and restore the health of the worker [10].

In order to adopt preventive measures in the work environment, it is necessary to take into account various aspects: Adequate postures, tasks done, furniture, and adoption of breaks. The consistent application of these and other practices, can be accomplished through ergonomic studies, the school of posture and labor gymnastics/kinesiotherapy GL/KL [10].

The school of posture enables a wide view of the human body and delineates the best way to care for and prevent potential diseases through inadequate habits $[18,12]$.

Some authors reported that even if the physical activity is done during working hours, it has an important influence in the prevention of diseases, the preservation of the worker's good physical health, enabling efficiency and efficacy in their activities,

*Corresponding author. Email: sanziar@gmail.com 
thereby contributing to the improvement of the worker's quality of life [1, 6-9,11,21].

The physiotherapist's job entails having a thorough knowledge and understanding of preventions, ergonomics and biomechanics. A physiotherapist with this knowledge can serve as an excellent manager of the life quality inside the work environment. In addition, the image of the company is improved and enhanced before its competitors through social programs, instituting community programs, with professionals habilitated to function in the service of prevention.

So, the objective of this study was to evaluate a labor kinesiotherapy program, associated to an educational program from Back School, about the effectiveness in the improvement in the quality of life in the workers from the production line of a X cigar factory.

\section{Methodology}

It is an interventional, longitudinal, field study, realized in the $\mathrm{X}$ cigar company, with 13 employees that work in the line of production from the period of November 2007 to March 2008.

Three interventions per week, involving two days of labor kinesiotherapy, divided into two moments consisting of stretching exercises and warm ups. The second one involved dynamics and relaxation techniques. The third day was posture school, educating the subject about the body and the proper way to care for it. The presentations were based on the posture school manual from the Federal University of Paraiba (UFPB), over 16 sessions. The company has 30 employees, of which 13 are employed in the production line and were participants in the study. The production was divided into 5 functions: 8 rollers (roll the cigars), 6 cappers (cap the cigars), 1 in the cigar preparation (cut the tips of the cigars), 1 in the opening of the cigar rolls (open the caps of the cigars), and 2 who packed the cigars. Only women who didn't have any pathology installed were included in this research (i.e. osteomoarticular, cardiac, neoplasic), who didn't participate in a posture school or didn't want to answer the questionnaire. All participants signed a consent form agreeing to participate in the research study, which was approved by the Research Ethics Committee at Faculdade Adventista de Fisioterapia (CCAE N ${ }^{\circ}$ 2570.0.000.070-07).

Data collection visits were made, to identify the place and the candidates following the inclusion and exclusion criteria. A genetic questionnaire of life quality (SF36) was used in the data collection, which is a multidimensional questionnaire made up of 36 items, including 8 domains that evaluate different health areas: Functional capacity, physical limitation, pain, vitality, social aspects, emotional aspects and mental health [19].

As an intervention method, the GL/KL was used, which is an exercise technique realized inside the work environment with the intention to improve the range of motion, strengthen and prepare the muscles for the activity, as well as promoting the mental and social well being [16].

Associated to GL/KL was the application of a program of corporal awareness, from the school of posture, which is a therapeuticpedagogical method consisting of theoretical information, practice of therapeutic exercises and relaxation training, with the final goal of self-education and a comprehension of the etiologic factors pertaining to back pain, following a self-care method by the Paraiba Federal University/UFPB [12] .

A test hypothesis was applied to verify whether or not there were similarities between the averages (before and after a professional physical therapy intervention) of the tabled variables, and to verify the existence of a significant, statistical difference between the same. The tests were applied with a $5 \%$ of significance or $95 \%$ of reliability.

\section{Results/discussion}

Graphics were made with the objective to organize, compare and obtain a better knowledge about the information gathered.

The before and after labor kinesiotherapy results were evaluated and compared, with the purpose of verifying the contribution of the labor kinesiotherapy in the life quality of the employees, presenting an improvement of 11,54 points in the functional capacity (FC), 6,23 points, limitation of physical aspects (LPA), 4,08 pain (P), 16,31 social aspects (SA), 10,25 emotional aspects (EA), 8,38 mental health $(\mathrm{MH}), 13,85$ health general state (HGS) and 6,15 vitality (V), according to Table 1. As for the hypothesis, it was found a statistically significant value of $\mathbf{p}$ for the FC, HGS and SA (Table 1), suggesting the rejection of $\mathrm{H}_{0}$, and confirming the improvement of the patient before and after the intervention of the domains cited.

$$
\text { Table } 1
$$

Initial average $(\mu \mathrm{i})$, final average $(\mu \mathrm{f})$, standard deviation (SD) and the value of $\mathbf{p}$ for each evaluated domain. 


\begin{tabular}{|c|l|l|c|}
\hline Domain & \multicolumn{1}{|c|}{$\mu \mathrm{i} \pm \mathrm{SD}$} & $\mu \mathrm{f} \pm \mathrm{DP}$ & $\mathbf{P}$ \\
\hline FC & $80 \pm 12,58$ & $\begin{array}{l}91,53846 \pm \\
9,48\end{array}$ & $0,001^{*}$ \\
\hline LPA & $67,30769 \pm 31,59$ & $\begin{array}{l}73,07692 \pm \\
3,19\end{array}$ & 0,61012 \\
\hline P & $65 \pm 28,05$ & $\begin{array}{l}69,07692 \pm \\
21,76\end{array}$ & 0,566087 \\
\hline HGS & $72,92308 \pm 15,12$ & $85 \pm 12,18$ & $0,041953^{*}$ \\
& & & \\
\hline V & $65,76923 \pm 23,19$ & $71,92308 \pm$ & 0,176051 \\
\hline SA & $75 \pm 20,22$ & $92,31 \pm 15,14$ & $0,01937^{*}$ \\
\hline EA & $79,49 \pm 30,77$ & $89,74 \pm 20,19$ & 0,303304 \\
\hline MH & $72,62 \pm 19,77$ & $80 \pm 19,29$ & 0,234745 \\
\hline
\end{tabular}

As for the LPA, P, V, EA, and MH, when the differences in the measurements were statistically significant, such facts can be related to the statistic error type II (not to find differences when these facts exist), suggesting the need for new studies with a larger sample for a new evaluation of the domains cited.

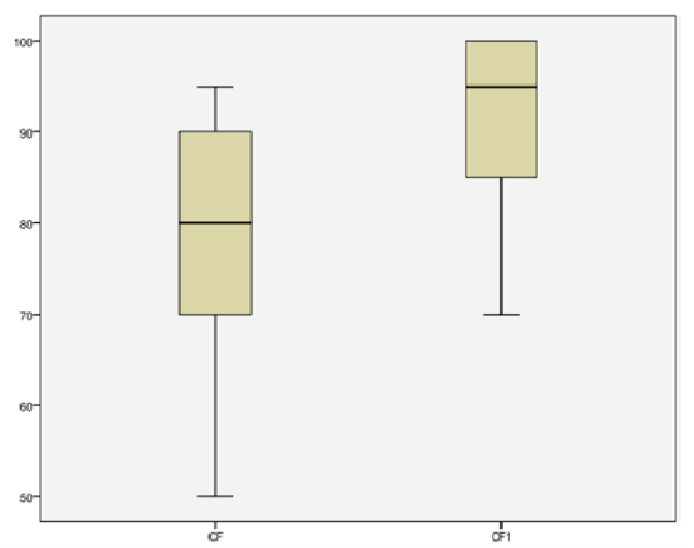
domain

Graph 01 . Comparative of the functional capacity

Source: Field research, 2008.

The GL/KL contributed in the freedom of movements of the articulations and to a better motor coordination, the balance and the flexibility, alleviating the overloads of the musculoskeletal unit, with physical exercises for muscles working very little, relaxed those that work excessively corroborating the improvement in the functional capacity and the general health $[14,16]$.

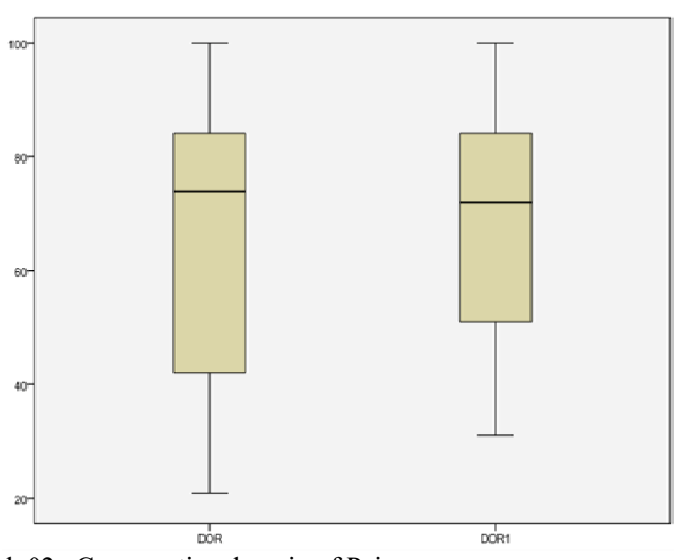

Graph 02. Comparative domain of Pain.

Source: Field research, 2007

As for the reduction of pain, studies proved the importance of the labor gymnastic in the pain reduction and an improvement in the quality of life of the employee $[15,6]$.

Others authors verified the pain complaints and the level of muscle shortening before and after the program of GL in 40 public employees, when it was noticed that the pain had a significant reduction in all body parts from $57 \%$ to $14 \%$, besides the reduction of muscle shortening [16].

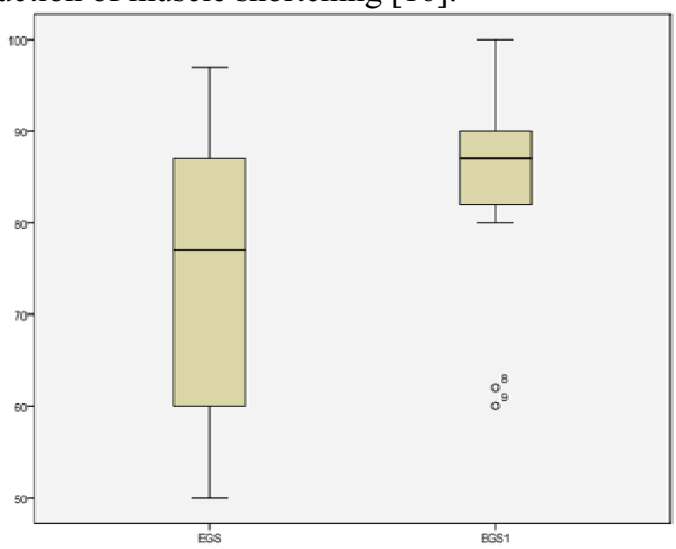

Comparative of the HGS domain.

Source: Field research, 2007.

In a study by Rodrigues et al ${ }^{[3]}$, he says that together with self-indulgence and sedentary habits, stressful factors at work (i.e. responsibilities, high production, market competition, self and social expectations, opportunities and perspectives of a career) makes people's life increasingly propitious in obtaining psychosomatic illnesses and a weak physical immunity. 


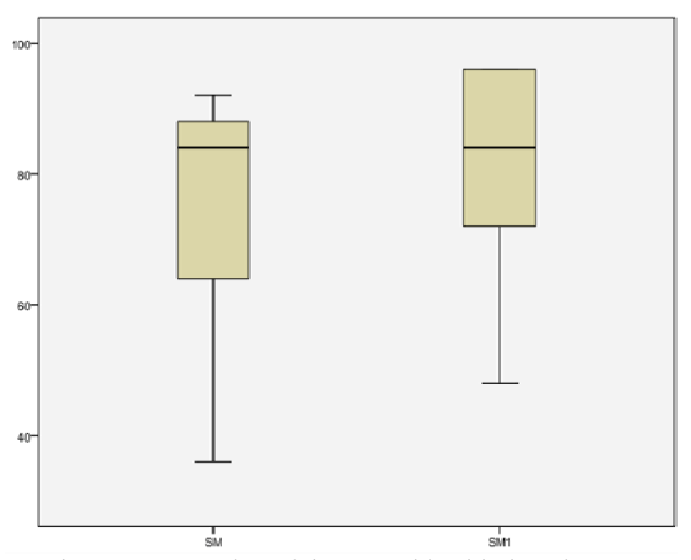

Graph 03. Comparative of the mental health domain. Source: Field research, 2008.

Besides the physical health, the physical activity also contributes to good mental health, intellectual and emotional, once the social and psychological effects are justified by the fact that physical activities favors relaxation, stimulates self-knowledge and increases self-esteem, providing a possible improvement in the interpersonal relationship with the worker's environment $[2,5-9.15,21]$

Ribeiro and Paim ${ }^{[17]}$ observed the implantation of the labor gymnastic. Employees of a plastic factory verified that besides having a noticeable improvement in their physical health, there were aspects in their interpersonal relationships which improved, as well as overall company satisfaction. In this study, employees reported increased motivation in their daily activities, as well as being more relaxed in their labor activities.

Lastly, when questioned about cramp symptoms, $83,3 \%$ of them answered that they had it and $16,6 \%$ didn't. After the intervention, $37,5 \%$ reported presenting this symptom against $62,5 \%$ who did not. There was also a reduction in the tingling sensation: $75 \%$ experienced this symptom before the intervention with $18,75 \%$ reporting not to have it. After the intervention, 62,5\% reported not feeling this sensation and only $37,5 \%$ presented this symptom showing the effectiveness of the KL and school of posture in the prevention of Repetitive Strain Injuries (RSI) present in the production of handmade cigars [22] corroborating with Junior[10] who proved the importance of KL through pause system during the work period, allowing reduction of muscle contractions and favoring the control and/or prevention of the following symptoms: tingling, pain, weak muscle strength and cramps, common in RSI levels II and III [10] .

\section{Conclusion}

Although the importance of GL/KL as a contributor to the worker's life quality is recognized, also we notice the lack of attention which many times is attributed to this method. This is why it is necessary to practice the KL, associated with posture school, in order to clarify their benefits as well as educate the employee to the various aspects which will optimize his/her efficiency.

It is known that the practice of only the exercises brings many benefits, and that this is incontestable because it prevents sedentarism and, consequently, the appearance of illnesses, contributing to the physical, mental and social well being of the worker.

However, the association with the Back School method, through educational and informative talks, contributed to a greater awareness of the workers about healthy habits, and his/her responsibility in the prevention process and not only by the responsibility of the GL/KL professional.

Finally, this study makes a contribution by proving that the implantation of the GL/KL and the school of posture in the work environment, makes possible a reduction of the harmful effects of inactivity, and prevents illness, while at the same time provides mental and social well being, which results in a better life quality, thus making the work environment more humanized. It was found that this was possible by the educative way that the school of posture has, and the higher understanding from the participating subjects as to the importance of adhering to the practical program, and the self-care in both daily life and labor activities.

It's noteworthy to underline the ergonomic aspects of the furniture change (chairs and height of the table) that was proposed. The recommendations of this study were not implemented, making impossible the evaluation of this aspect. It's suggested that new studies in this area take into account the implementation of the ergonomic measures for the adequacy of the furniture, optimizing the benefits for both employees and the company, by the implementation of the GL/KL and Posture School Programs.

\section{References}

[1] A.F. dos Santos et al. Benefícios da ginástica laboral na prevenção dos distúrbios osteomusculares relacionados ao trabalho. Bireme. Lilacs. Arq.Ciênc. Saúde Unipar, Umuarama, v.11, n.2, p. 107-113, maio/ago. 2007.

[2] C.N.Silva, A.T.Silva, F.M.Gervasio. Prevalência e Aplicação da Classificação de Mckenzie para 
Lombalgia em Funcionários do Centro Universitário UniEVANGÉLICA.. Anápolis, 2006. Disponível em: http://www.unievangelica.edu.br/noticias>. Acesso dia 18 março 2010.

[3] E.P.V.Rodrigues. Cartilha LER/DORT: prevenção é o melhor remédio. 1 ed. São Paulo: FEAAC.2004

[4] E.Z. Caraviello et al. Avaliação da dor e função de pacientes com lombalgia tratados com um programa de Escola de Coluna. ACTA FISIATR, São Paulo,v.12, n.1, p.11-14, 2005.Disponível em: $<$ http://www.actafisiatrica.org.br $>$. Acesso 08 fev. 2010

[5] H.A.Couto. Como Implantar Ergonomia na Empresa. A prática dos comitês de ergonomia. Belo Horizonte: Ergo, 2007.

[6] I. Lampert. A influência de um programa de cinesioterapia laboral para a qualidade de vida dos funcionários do hospital São Vincente de Paulo. Fisiobrasil, Espírito Santo, ano 10, n.77, p.33, Maio, 2006.

[7] I. de Souza, R.J. Venditti. Ginástica laboral: contribuições para a saúde e qualidade de vida de trabalhadores da indústria de construção e montagem - Case TECHINT S.A. Buenos Aires, outubro 2004. Disponível em: < http://www.efdeportes.com $>$. Acesso dia $10 \mathrm{de}$ marco 2010

[8] J.A. C. A Leme, E.C. Meyer. Efeito da ginástica laboral na qualidade de vida de trabalhadores. Bireme.Lilacs. Cienc.Trab., v.10, nº 29, p. 100-105, jul-set, 2008.

[9] J.R.G. de OLIVEIRA. A importância da ginástica laboral na prevenção de doenças ocupacionais. Revista de Educação Física, Prefeitura Municipal de Sorriso. Faculdade Centro Mato-Grossense Sorriso, Brasil, v.139, p.40-49, 2007.

[10] J.R.V.Junior. Fisioterapia do trabalho: cuidando da saúde funcional do trabalhador. 1 ed. São Paulo:Andreolli, 2008.

[11] L. G. Barbosa. Fisioterapia preventiva nos distúrbios osteomusculares relacionados ao trabalho - DORTS - A fisioterapia do trabalho aplicado. 1.ed. Rio de Janeiro: Editora guanabara koogan S.A, 2002.
[12] M. C. G.Cardia. Manual da escola de postura da UFPB. 3 ed. Paraíba: UFPB, 2006.

[13] MINISTÉRIO DA PREVIDÊNCIA SOCIAL, Anuário Estatística da Previdência Social, 2009. Disponível em: < http://www. Ministério da Previdência Social.htm> Acesso em: 28/04/2011.

[14] P.C.P. Deliberato. Fisioterapia preventiva: fundamentos e aplicações.1ed.São Paulo: Manole, 2002.

[15] P.H.M. CIRELLI, G.Cirelli, P.R.S. Benicios. A importância da ginástica laboral na diminuição das algias e melhora da qualidade de vida do trabalhador. Fisioterapia Brasil, Rio de Janeiro, ano 6, n.5, p.349 a 353, setembro/outubro, 2005.

[16] R.A.Mendes, N. Leite. Ginástica laboral: Princípios e aplicações práticas, 2004

[17] S. B.Ribeiro, S.T. Paim. Analise ergonômica associada a ginástica laboral na qualidade de vida de trabalhadores de uma linha de produção. Proteção, São Paulo, ano 22, n.215, PP 62-67,Novembro, 2009.

[18] S. C.Andrade, A. G. R de Araujo e M.J.P. Villar. Escola de postura: Revisão histórica e suas aplicações na lombalgia crônica. ], São Paulo, v.45, n.4, jul/ago, 2005.

[19] Severo et al. Confiabilidade e validade dos conceitos teóricos das dimensões de saúde física e mental da versão portuguesa do MOS SF-36*. Porto, julho 2006. Disponível em: $<$ http://www.actamedicaportuguesa.com/pdf $>$.Acess o dia 08 abril 2011.

[20] S.Moretti, A. Treichel. Qualidade de Vida no Trabalho e auto-Realização Humana. Revista Leonardo pós-Órgão de Divulgação Científica e Cultural do ICPG, Blumenau, 1,3, pp.73-80, 2003.

[21]W.C.Longen. Ginástica laboral na prevenção de LER/DORT: Um estudo reflexivo em uma linha de produção. Florianópolis, 2003. Acesso em: novembro de 2007.

[22] W.T.Cunha Acepcão de risco de adoecimento em LER/DORT por charuteiras. Dissertação (Mestre) Universidade Federal da Bahia. Faculdade de Medicina. Curso em Pós-Graduação Mestrado em Saúde, Ambiente e Trabalho. Salvador, 2010. Acesso em: 